\title{
Correction to: Designing flexible loop-based material handling AGV paths with cell-adjacency priorities: an efficient cutting-plane algorithm
}

\author{
Amir Ahmadi-Javid ${ }^{1} \cdot$ Nasrin Ramshe $^{1}$ \\ Published online: 23 June 2020 \\ C) Springer-Verlag GmbH Germany, part of Springer Nature 2020
}

\section{Correction to: 4OR-Q J Oper Res 17:373-400 https://doi.org/10.1007/s10288-018-0383-5}

In the original publication of the article, the corresponding author name was incorrectly published as "Ahamdi-Javid". The correct name should read as "Ahmadi-Javid".

The original article has been corrected.

Publisher's Note Springer Nature remains neutral with regard to jurisdictional claims in published maps and institutional affiliations.

The original article can be found online at https://doi.org/10.1007/s10288-018-0383-5.

$凶$ Amir Ahmadi-Javid

ahmadi_javid@aut.ac.ir

1 Department of Industrial Engineering \& Management Systems, Amirkabir University of Technology, Tehran, Iran 